\title{
A coronariarendszer komputertomográfiás vizsgálata - Országos Plakk Regiszter és Adatbázis (OPeRA)
}

\author{
Bagyura Zsolt dr. - Kolossváry Márton dr. \\ Merkely Béla dr. - Maurovich-Horvat Pál dr.
}

Magyar Tudományos Akadémia-Semmelweis Egyetem „Lendület” Cardiovascularis Képalkotó Kutatócsoport, Szív- és Érgyógyászati Klinika, Semmelweis Egyetem

\begin{abstract}
Bevezetés: A coronaria komputertomográfiás angiográfia az egyetlen nem invazív vizsgálómódszer, amely a plakkok mennyiségéről, helyéről, illetve szerkezetéről ad információt, így alkalmas a koszorúér-betegség, illetve a fokozott rizikójú betegek azonosítására. Nagy esetszámú regiszterek létrehozásának legfőbb nehézségét a vizsgálati eredmények adatbázisba és a kórházi informatikai rendszerbe párhuzamosan történő kettős rögzítése jelenti. Célkitüzés: A coronaria komputertomográfiás vizsgálatok eredményeinek kutatásban való felhasználásához megbízható regiszter kialakítása. Módszer: Klinikai leletezéssel egy időben tudományos igényű adatrögzítést is lehetővé tevő strukturált leletezőeljáráson alapuló regisztert alakítottunk ki. Az adatbevitelt követően automatikusan hozzuk létre a nemzetközi irányelveknek megfelelő leletet. Eredmények: 2014. augusztus 1. és 2015. szeptember 1. között 2866 beteg adatát rögzítettük. A betegek 77,03\%-ánál találtunk coronariaplakkot, amelynek 33,18\%-a kalcifikált elváltozás. Súlyos fokú szúkülettel 13,71\%-uk rendelkezett. Következtetések: A strukturált leletezés használata növeli az adatbevitel sebességét, kiiktatja a kettős adatbevitelt és csökkenti a hibalehetőségek számát. További célunk egy országos rendszer, az Országos Plakk Regiszter és Adatbázis létrehozása. Orv. Hetil., 2017, 158(3), 106-110.
\end{abstract}

Kulcsszavak: coronaria-CT-angiográfia, strukturált leletezés, regiszterek

\section{Computer tomography examination of the coronary system - National Plaque Registry and Database, Hungary}

Introduction and aim: Coronary computer tomography angiography is a unique non-invasive imaging technique with the capability to provide information regarding plaque quantity, burden and structure. A reliable registry is required to use the data of these examinations in research projects. The difficulty is that registries need double data entry simultaneously to the hospital information system. Method: Our registry solves this problem through a structured reporting tool, which generates clinical report and stores all data simultaneously. The automatically generated report is based on international guidelines. Results: Between August 1. 2014 and September 1. 2015 we registered the data of 2866 patients. Coronary plaque was observed in $77.03 \%$ of the patients, $33.18 \%$ of the plaques were calcified. Severe stenosis was present in $13.71 \%$ of the patients. Conclusions: The structured reporting decreases reporting time, eliminates double data entry related errors. Our goal is to initiate a nationwide, unified registry, the National Plaque Registry and Database.

Keywords: coronary CT angiography, structured reporting, registry

Bagyura, Zs., Kolossváry, M., Merkely, B., Maurovich-Horvat, P. [Computer tomography examination of the coronary system - National Plaque Registry and Database, Hungary]. Orv. Hetil., 2017, 158(3), 106-110.

(Beérkezett: 2016. november 7.; elfogadva: 2016. november 24.) 


\section{Rövidítések}

AHA = American Heart Association; CAD-RADS = Coronary Artery Disease Reporting and Data System; CTA = computed tomography angiography; DICOM = Digital Imaging and Communications in Medicine; $\mathrm{mSv}=$ millisievert; $\mathrm{MTA}-\mathrm{SE}=$ Magyar Tudományos Akadémia-Semmelweis Egyetem; OPeRA = Országos Plakk Regiszter és Adatbázis; SCCT = Society of Cardiovascular Computer Tomography

A szív- és érrendszeri betegségek vezetik a mortalitási és morbiditási statisztikákat, az Európai Unióban évente mintegy 4,1 millió ember halálát okozva [1], így mind társadalmilag, mind gazdaságilag számottevô terhet jelentenek Európa számára. Hazánkban a szívinfarktus incidenciája háromszorosa az Európai Unió átlagának: évente mintegy 20000 ember szenved el szívizominfarktust [2].

A veszélyeztetett betegek döntő többségének nincsenek mellkasi panaszai, és a koszorúér-betegség első megnyilvánulása a szívinfarktus vagy hirtelen szívhalál. Kórbonctani vizsgálatok feltárták, hogy a szívizominfarktust és/vagy hirtelen szívhalált elszenvedett betegek kétharmadánál korábban érdemi lumenszúkuületet nem okozó, úgynevezett vulnerabilis plakk rupturája okozza a koszorúér-trombosist $[3,4]$. A koszorúér-betegséghez köthető mortalitási és morbiditási statisztikák további jelentős javításának egyik leghatékonyabb lehetőségét a prevenciós stratégiák erősítése jelenti $[5,6]$. Jelenleg a coronaria komputertomográfiás angiográfia (CTA) az egyetlen olyan nem invazív módszer, amely a plakkok mennyiségérôl, helyéról, illetve a plakk szerkezetéról információt ad [3], így alkalmas lehet a coronaria atherosclerosis és a fokozott rizikójú betegek azonosítására.

A közelmúltban számos nemzetközi vizsgálat igazolta a coronaria-CTA jelentőségét a személyre szabott rizikóbecslésben. Az alacsony sugárdózisú, natív CT-vel végzett rizikóbecslés (Calcium-scoring, Agatston-score) pontosabb rizikóbecslést tesz lehetővé a hagyományos módszereknél [7]. A kontrasztanyag adásával végzett coronaria-CTA-val a kalcifikált plakkokon felül a nem kalcifikált plakk-komponensek is azonosíthatók [8]. A coronaria-CTA-n ábrázolódó plakkok mennyiségének, elhelyezkedésének és egyéb képi markereknek komoly prognosztikai jelentőségük van a cardiovascularis események tekintetében. A koszorúér-CTA-felvételek eredményeiból származó adatok és a beteg klinikai paramétereinek együttes elemzésével a klinikai gyakorlatban használható rizikóbecslő eszköz kialakítására nyílhat lehetőség. A klinikai és képi markerek együttes alkalmazásával kialakított hibrid, személyre szabott rizikóbecslés a hagyományos rizikóscore-oknál hatékonyabban azonosíthatja a nagy cardiovascularis kockázatú betegeket. Ez idáig nem állt rendelkezésre megfelelő nagyságú és igényességű adatbázis, amely lehetôvé tenné a fenti elemzéseket. A kórházi informatikai rendszerekben és radiológiai rendszerekben található leletek utólagos feldolgozása nem teszi le- hetővé ilyen adatbázis kialakítását. Egy kellő részletességü és méretú prospektív adatbázis, a betegek - és így a plakkok - hosszú távú követésével lehetővé tenné a személyre szabott rizikóscore kialakítását és a vulnerabilitási képi markerek prognosztikai értékének vizsgálatát.

A klinikai adatbázisok, regiszterek építésének a legnagyobb nehézsége, hogy a rutin-leletkészítés feladata mellett a tudományos igényességú adatbázis létrehozása további adminisztrációs terhet jelent. Ez a kettős adatbevitel időigényes, ezért roppant költséges és megnyújtja az adatrögzítés idejét, ráadásul önmagában hibaforrás az ismételt adatrögzítés miatt. Mivel a kutatható adatbázisok jellemzően több, illetve részletesebb adatot igényelnek a rutinleletekhez képest, a regiszterbe történő utólagos adatbevitel további nehézségei közé tartozik, hogy a forrásdokumentáció nem tartalmazza minden esetben az összes rögzíteni kívánt információt. Ennek legfontosabb oka, hogy szabad szöveges, nem célzott tudományos igényességú adatrögzítés történik a rutin klinikai leletezés folyamán. Továbbá jelenleg nincs egységesen elfogadott leletstruktúra, nincs meghatározva az elvárt minimális adattartalom, ezért minőségi és tartalombeli különbségek mutatkoznak a radiológiai leletek között. E problémákra jelent megoldást, ha strukturáltan rögzítjük az adatokat, majd informatikai eszközökkel a részletes adatbázisból automatikusan generáljuk a klinikai leletet. Így az adatgyújtés nem, vagy csak minimális mértékben jelent többletterhet a személyzet számára a rutinellátáshoz képest.

\section{Célkitüzések}

Célul tưztük ki strukturált coronaria-CTA-leletező rendszer kialakítását, amelynek használatával a rutin klinikai leletezés mellett egy időben a regiszterbe történó, tudományos igényú adatrögzítés is megvalósul. Ennek keretében célunk volt:

- Egységes, standardizált coronaria-CTA-leletezés módszertanának (leletezési protokoll és adattartalom) és informatikai háttérének kialakítása.

- Strukturált leletezés és regiszter integrálása a klinikai betegellátásba, hogy minden, intézetünkben végzett vizsgálat eredménye bekerülhessen az adatbázisba, illetve a tudományos elemzéshez szükséges egyéb adatok szisztematikus gyújtése.

- A képminőség, sugárdózis, kontrasztanyag-mennyiség folyamatos ellenőrzése (quality control), szövődmények rögzítése (safety control).

- Az adatbázis kiterjesztése más centrumok felé, Országos Plakk Regiszter és Adatbázis (OPeRA) létrehozása.

- A fenti adatok birtokában a magyar lakosságra vonatkozó, képi és klinikai adatokat egyaránt magába foglaló, személyre szabott rizikóbecslő pontrendszer (OPeRA-score) kifejlesztése és a pontrendszer prognosztikai értékének meghatározása. 


\section{Módszer}

A Semmelweis Egyetem Városmajori Szív- és Érgyógyászati Klinikáján az MTA-SE „Lendület” Cardiovascularis Képalkotó Kutatócsoport által kialakításra került coronaria-CTA-leletező rendszer megteremti annak lehetôségét, hogy a klinikai leletezés egyben a regiszterbe történő, tudományos igényű adatrögzítés is legyen. A rendszer a leletezés során az adatbevitelt modern, webes technológiákat alkalmazó felülettel könnyíti meg. A leletezési protokollt a Society of Cardiovascular Computer Tomography (SCCT), a Magyar Kardiológusok Társasága és a Magyar Radiológusok Társasága ajánlásai alapján dolgoztuk ki [9]. Az adatbevitelt követően a nemzetközi protokolloknak megfelelő coronaria-CTAvizsgálati lelet automatikusan létrejön [10], így a leletezés és a regiszterépítés (adatrögzítés) nem jelent megnövekedett terhet a személyzet számára.

A lelet generálásával párhuzamosan a koszorúereken azonosított elváltozások és egyéb jellegzetességek numerikus formában, anonim módon kerülnek tárolásra a regiszterben. Az általunk fejlesztett leletezőrendszer végigvezeti az orvost a leletkészítés folyamatán, így biztosítva, hogy minden fontos információ bekerüljön a rendszerbe. A kötelező és egymástól függő adatbeviteli mezők rendszere biztosítja, hogy még negatív lelet esetén is minden tudományos szempontból fontos adat és információ rögzítésre kerüljön. Ezen túlmenően a vizsgálathoz kapcsolódó egyéb jelentős információk (sugárdózis, kontrasztanyag mennyisége, gyógyszerelés) is rögzítettek, a technikai paraméterek automatikusan átvételre kerülnek a CT-gépből (DICOM-kommunikáció), így azok kézi bevitelére nincs szükség. A rendszerben a tudományos kutatáshoz nélkülözhetetlen egyéb klinikai adatok bevitelére alkalmas felület is található, amelybe az önbevallásos kérdőívek és a betegdokumentáció alapján a leletezés során vagy utólag kerülnek rögzítésre az információk. Ezek mellett a kész lelet automatikusan kerül be az illesztett kórházi rendszerbe, ezzel minimalizálva a hibalehetőségeket (1. ábra).

A) Klinikai adatrögzítés általánosan alkalmazott módszere

Beteg $\underset{\text { Vizsgáló } 1}{\Rightarrow} \begin{gathered}\text { Kórházi } \\ \text { informatikai } \\ \text { rendszer }\end{gathered} \underset{\text { Vizsgáló } 2}{\longrightarrow} \begin{gathered}\text { Tudományos } \\ \text { adatbázis }\end{gathered}$

B) Klinikai adatrögzítés a coronaria-CTA-regiszterben

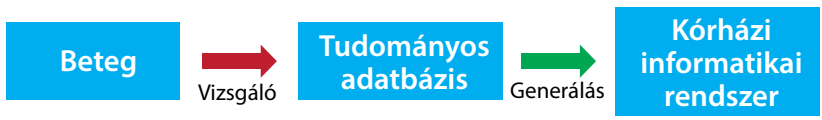

1. ábra

Klinikai adatrögzítés általánosan alkalmazott (A), illetve a coronaria-CTA-regiszterünkben alkalmazott módszere (B)

\section{Eredmények}

A Semmelweis Egyetem Városmajori Szív- és Érgyógyászati Klinikáján a coronaria-CTA-vizsgálatok leletezése 2014 februárja óta ebben a rendszerben történik. Első lépésként létrehoztuk a nemzetközi ajánlásoknak megfelelő strukturált lelet formátumot, illetve az adatrögzítéshez szükséges felületet.

2014. augusztus 1. és 2015. szeptember 1. között 2866 konszekutív beteg (kor: 59,5 $\pm 11,9$ év, 41,3\% nő) adatát rögzítettük a regiszterünkben. Feltételezett coronariabetegség volt a leggyakoribb indikáció $(60,1 \%)$, amelyet a bal pitvari angiográfia követett $(20,3 \%)$. A betegek 90,6\%-ának sinusrhythmusa volt a vizsgálat alatt (átlagfrekvencia: $61,6 \pm 12,61 / \mathrm{min}$ ). A vizsgálatok 98,5\%-a prospektív EKG-kapuzással készült. Az átlag effektív sugárdózis 4,0 $\pm 1,4 \mathrm{mSv}$ volt, míg a Ca-scorevizsgálatoké $0,5 \pm 0,2 \mathrm{mSv}$. Premedikáció során a betegek $68,3 \%$-a kapott metoprololt, 4,1\%-a ivabradint és 98,5\%-a nitroglicerint. A betegek 14,3\%-ának javasoltunk invazív coronaria-angiográfiát. A betegek 47,0\%ának statinterápiát indikáltunk enyhe-közepes fokú coronariaatherosclerosis miatt. A coronaria-CTA-vizsgálatok során a betegek 77,03\%-ánál találtunk coronariaplakkot. A betegeknél átlagosan 3,46 coronariaszegmentum volt érintett. Súlyos fokú szúkülettel a betegek 13,71\%-a rendelkezett (1. táblázat). A plakkok 33,18\%-a kalcifikált, $39,49 \%$-a részben meszes és 27,33\%-a nem kalcifikált plakk volt.

A coronaria-CTA elemzése során gyüjtött adatok azonnal feldolgozásra kerülnek, amelyek alapján számos score-t és az adott betegre vonatkozó elemzést készítünk, amely már a leletezés során segíti a klinikust a leletkészítésben és a döntéshozatalban. Ilyen score például a CAD-RADS (Coronary Artery Disease Reporting and Data System) [11], amely egy standardizált rendszer a coronaria-CT-angiográfiás vizsgálatok eredményeinek értékelésére, amely segíti a beteg további kezelésével kapcsolatos döntések meghozatalát (2. táblázat).

\section{Következtetések}

A kezdeti időszak során nyert tapasztalatok alapján sikerült egy, a napi ellátásban használható, szabadon paraméterezhető adatrögzítő rendszert kialakítanunk, amelynek használata nem növeli meg a leletkészítés idejét, kellően rugalmas, kereshető, statisztikailag értékelhető adatbázist szolgáltat. Klinikánkon az összes coronaria-CTAvizsgálat ebben a rendszerben kerül rögzítésre, amely éves szinten megközelítőleg 2700 vizsgálatot jelent. Jelenleg a Városmajori Szív- és Érgyógyászati Klinikán indított coronaria-CTA-regiszter kiterjesztését végezzük más diagnosztikai központok bevonásával, ez idáig 11 centrum jelezte csatlakozási szándékát. Az általunk használt rendszer megteremti egy országos, egységes rendszer, az Országos Plakk Regiszter és Adatbázis (OPeRA) alapját, amely várhatóan évi 5500 vizsgálat eredményeit 
1. táblázat | Demográfia, vizsgálati paraméterek és javaslat $(\mathrm{n}=2866)$

\begin{tabular}{|c|c|c|}
\hline \multicolumn{2}{|l|}{ Kor } & $59,5 \pm 11,9$ év \\
\hline \multicolumn{2}{|l|}{ Férfi nem } & $58,7 \%$ \\
\hline \multicolumn{2}{|l|}{ Magasság } & $171,5 \pm 10,7 \mathrm{~cm}$ \\
\hline \multicolumn{2}{|l|}{ Súly } & $84,1 \pm 17,6 \mathrm{~kg}$ \\
\hline \multicolumn{2}{|l|}{ Derékkörfogat } & $98,3 \pm 13,9 \mathrm{~cm}$ \\
\hline \multicolumn{2}{|l|}{ Magas vérnyomás } & $70,0 \%$ \\
\hline \multicolumn{2}{|l|}{ Diabetes mellitus } & $16,2 \%$ \\
\hline \multicolumn{2}{|l|}{ Dyslipidaemia } & $46,3 \%$ \\
\hline \multicolumn{2}{|l|}{ Aktív dohányzás } & $41,9 \%$ \\
\hline \multicolumn{2}{|c|}{ Prospektív EKG-triggerelés } & $99,8 \%$ \\
\hline \multirow[t]{2}{*}{ Legjobb fázis $\mathrm{R}-\mathrm{R}$} & $78 \%$ & $38,6 \%$ \\
\hline & $81 \%$ & $38,5 \%$ \\
\hline \multicolumn{2}{|l|}{ CTA effektív dózis } & $4,0 \pm 1,4 \mathrm{mSv}$ \\
\hline \multicolumn{2}{|c|}{ Ca-score effektív dózis } & $0,5 \pm 0,2 \mathrm{mSv}$ \\
\hline \multirow[t]{2}{*}{ Szívritmus } & Sinus & $90,5 \%$ \\
\hline & Pitvarfibrilláció & $8,3 \%$ \\
\hline \multicolumn{2}{|l|}{ Szívfrekvencia } & $61,6 \pm 12,61 / \mathrm{min}$ \\
\hline \multicolumn{2}{|c|}{ Kontrasztanyag-mennyiség } & $91,3 \pm 8,0 \mathrm{ml}$ \\
\hline \multicolumn{2}{|c|}{ Invazív koronarográfia javaslat } & $14,3 \%$ \\
\hline \multicolumn{2}{|c|}{ Coronariaplakk } & $77,03 \%$ \\
\hline \multicolumn{2}{|c|}{ Érintett szegmentumok átlagos száma } & 3,46 \\
\hline \multicolumn{2}{|c|}{ Súlyos fokú szúküulettel rendelkező betegek } & $13,71 \%$ \\
\hline
\end{tabular}

tárolja majd. Ez idáig Magyarországon fóként betegregiszterek múködtek (többek között: Nemzeti Rákregiszter, Nemzeti Szívinfarktus Regiszter, Veleszületett Rendellenességek Országos Nyilvántartása, Magyar Szívelégtelenség Regiszter). Kezdeményezésünk újszerüségét a megközelítésen túl az adja, hogy egy diagnosztikai eljárás adatait gyújtő regiszter kialakítását végezzük. Ehhez hasonló országos szintű összefogást semelyik külföldi országban nem sikerült eddig elérni a diagnosztikai centrumok között. A legalább hároméves utánkövetés és a vezető koszorúér-CT-centrumok országos szintü részvétele garantálja a nagyszámú betegadat rögzítését, amelyek között jelentős számú ismételt, kontroll-CT-vizsgálat is szerepel majd a panaszok rosszabbodása vagy a beültetett koszorúérstentek ellenőrzése miatt. Az ismételt vizsgálatok különösen értékes adatokat szolgáltatnak majd a koszorúér-elváltozások progressziójával kapcsolatos klinikai és képi adatokat illetően. Prospektív regiszterünk kellően részletes, jó minőségű adatokat tartalmaz, a betegek - és így a plakkok - hosszú távú követésével lehetővé teszi a személyre szabott rizikóscore kialakítását és a vulnerabilitási képi markerek prognosztikai értékének vizsgálatát. A fentieken kívül a strukturált adatbeviteli módszernek közvetlen pozitív hatása van a coronaria-CTA-leletezésre, javul a leletek megbízhatósága és a klinikusok számára könnyebben értelmezhetôvé válnak a leletek - a standardizációnak köszönhetően.
2. táblázat $\mid$ Az adatbevitel során azonnal meghatározásra kerülő score-ok és statisztikák, amelyek segítik a klinikust a döntéshozatalban és későbbi elemzésekben felhasználhatók

\section{Döntéstámogatás}

CAD-RADS - Coronary Artery Disease

Reporting and Data System

\section{Páciensscore-ok}

- Segment Stenosis Score és Index

- Segment Involvement Score és Index

- Leaman score, módosított Duke-score

\section{Minőségbiztosítás}

A vizsgálat indokoltságának automatikus értékelése az American Heart Association (AHA) kritériuma alapján:

- Appropriate use criteria

- Diamond and Forrester pre-test valószínúség

\section{Plakkscore-ok}

- Kalcifikált, nem kalcifikált és meszes plakkok száma

- Különböző attenuációs mintázatok száma (például Napkin ring jel)

- Plakktípusok száma

Éralapú score-ok

- Háromér-pontrendszer

- Főtörzsérintettség

Ca-score

- Agatston-score

- Percentilisek meghatározása

\section{Szegmentumalapú score-ok}

- Különböző súlyossági kategóriák száma

- Stentek és bridgek száma

Anyagi támogatás: A regiszter megvalósulását anyagilag az MTA-SE „Lendület” Cardiovascularis Képalkotó Kutatócsoport és a Semmelweis Egyetem, Városmajori Szív- és Érgyógyászati Klinika támogatta.

Szerzői munkamegosztás: B. Zs., K. M., M. B., M-H. P.: A regiszter tervezése. B. Zs., K. M., M-H. P.: A regiszter kidolgozása. A cikk végleges változatát valamennyi szerzô elolvasta és jóváhagyta.

Érdekeltségek: A szerzőknek nincsenek érdekeltségeik.

\section{Köszönetnyilvánítás}

A szerzők köszönik Dr. Szilveszter Bálint, Dr. Karády Júlia, Dr. Károlyi Mibály, Dr. Bartykowszki Andrea, Dr. Panajotu Alexisz és Dr. Jermendy Ádám segítségét a regiszter kialakításában. 


\section{Irodalom}

[1] Nichols, M. N., Townsend, P., Scarborough, et al.: Cardiovascular disease in Europe: epidemiological update. Eur. Heart J., 2013, 34(39), 3028-3034.

[2] Jánosi, A., Ofner P., Branyickiné Géczy, G., et al.: Incidence of myocardial infarction in Hungary. Population study in five districts of Budapest and Szabolcs-Szatmar-Bereg county. [A szívinfarktus incidenciája Magyarországon. Epidemiológiai vizsgálat Budapest öt kerületében és Szabolcs-Szatmár-Bereg megyében.] Orv. Hetil., 2013, 154(28), 1106-1110. [Hungarian]

[3] Maurovich-Horvat, P., Ferencik, M., Voros, S., et al.: Comprehensive plaque assessment by coronary CT angiography. Nat. Rev. Cardiol., 2014, 11(7), 390-402.

[4] Narula, J., Garg, P., Achenbach, S., et al.: Arithmetic of vulnerable plaques for noninvasive imaging. Nat. Clin. Pract. Cardiovasc. Med., 2008, 5(Suppl. 2), S2-S10.

[5] Braunwald, E.: Epilogue: what do clinicians expect from imagers? J. Am. Coll. Cardiol., 2006, 47(8 Suppl.), Cl01-C103.

[6] Narula, J., Strauss, H. W.: The popcorn plaques. Nat. Med., 2007, 13(5), 532-534

[7] Martin, S. S., Blaha, M. J., Blankstein, R., et al.: Dyslipidemia, coronary artery calcium, and incident atherosclerotic cardiovascular disease: implications for statin therapy from the multi-ethnic study of atherosclerosis. Circulation, 2014, 129(1), 77-86.

[8] Maurovich-Horvat, P., Ferencik, M., Bamberg, F., et al.: Methods of plaque quantification and characterization by cardiac computed tomography. J. Cardiovasc. Comput. Tomogr., 2009, 3(Suppl. 2), S91-S98.
[9] Maurovich-Horvat, P., Bartykowszki, A., Kerecsen, G., et al.: Coronary computed tomographic angiography reporting - Recommendations of the Working Group of Cardiovascular Computed Tomography of the Hungarian Society of Cardiology and the Cardiac Imaging Diagnostic Section of the Hungarian Society of Radiologists. [A koronária-CT-angiográfia leletezése. A Magyar Kardiológusok Társasága Szív-CT Munkacsoportjának és a Magyar Radiológusok Társasága Szív Képalkotó Diagnosztikai Szekciójának közös ajánlása.] Cardiologia Hungarica, 2013, 43(5), 275-281. [Hungarian]

[10] Leipsic, J., Abbara, S., Achenbach, S., et al.: SCCT guidelines for the interpretation and reporting of coronary CT angiography: a report of the Society of Cardiovascular Computed Tomography Guidelines Committee. J. Cardiovasc. Comput. Tomogr., $2014,8(5), 342-358$.

[11] Cury, R. C., Abbara, S., Achenbach, S., et al.: CAD-RADS ${ }^{\mathrm{TM}}$ Coronary Artery Disease - Reporting and Data System. An expert consensus document of the Society of Cardiovascular Computed Tomography (SCCT), the American College of Radiology (ACR) and the North American Society for Cardiovascular Imaging (NASCI). Endorsed by the American College of Cardiology. J. Cardiovasc. Comput. Tomogr., 2016, 10(4), 269-281.

(Bagyura Zsolt dr., Budapest, Városmajor u. 68., 1122 e-mail: bagyura.zsolt@kardio.sote.hu)

\section{Ellen Notbohm-Veronica Zysk} EZEREGY NAGYSZERRUU ÖTLET

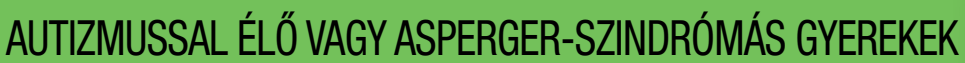
NEVELÉSÉHEZ ÉS TANÍTÁSÁHOZ

„Ha minden iskolában és családban a könyvben szereplő ötletek kis töredékét felhasználnák, beláthatatlan lehetöségek nyilnának meg elöttünk, hogy javítsuk az autizmussal vagy Asperger-szindrómával élö gyermekek életminőségét. Ez pedig csodálatos dolog!"

A könyv számtalan azonnal alkalmazható ötletet kínál szülőknek és nevelőknek az alábbi területeken:

- szenzoros integráció: fejlesztőfeladatok a szabadban és bent,

- kommunikáció: szóhasználat, hallás, vizualitás, környezet,

- viselkedés: tipikus viselkedési formák és kezelésük,

- mindennapi élet: ötletek a mindennapi szituációkhoz, a biztonság megteremtéséhez,

- szociális létezés: barátság, játék, kooperáció, érzelmek.

\section{ET}

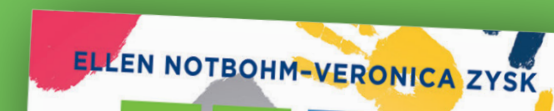

